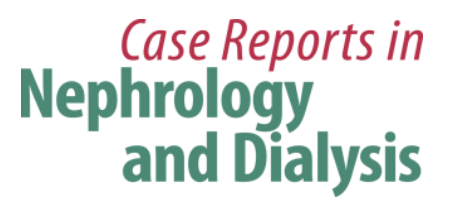

Case Rep Nephrol Dial 2016;6:89-95

DOI: $10.1159 / 000448025$

Published onlıne: July 19, 2016

(C) 2016 The Author(s)

Published by S. Karger AG, Basel

www.karger.com/cnd

This article is licensed under the Creative Commons Attribution-NonCommercial 4.0 International License (CC BY-NC) (http://www.karger.com/Services/OpenAccessLicense). Usage and distribution for commercial purposes requires written permission.

\title{
Coexistence of Acute Crescent Glomerulonephritis and IgG4-Related Kidney Disease
}

\author{
Zeyuan $\mathrm{Lu}^{\mathrm{a}}$ Jianyong Yin ${ }^{\mathrm{a}} \mathrm{Hongda}^{\mathrm{Bao}}{ }^{\mathrm{a}}$ Qiong Jiao ${ }^{\mathrm{b}}$ Huijuan $\mathrm{Wu}^{\mathrm{c}}$ \\ Rui Wu $^{a}$ Qin Xue ${ }^{a}$ Niansong Wang ${ }^{a}$ Zhigang Zhang ${ }^{c} \quad$ Feng Wang $^{a}$ \\ ${ }^{a}$ Department of Nephrology and Rheumatology, Shanghai Jiao Tong University Affiliated \\ Sixth People's Hospital, Shanghai, China; ${ }^{b}$ Department of Pathology, Shanghai Jiao Tong \\ University Affiliated Sixth People's Hospital, Shanghai, China; ${ }^{\mathrm{C} D e p a r t m e n t}$ of Pathology, \\ Fudan University School of Medicine, Shanghai, China
}

\section{Keywords}

IgG4-related disease · IgG4-related kidney disease · IgG4-related tubulointerstitial nephritis · Acute crescent glomerulonephritis

\begin{abstract}
Introduction: IgG4-related disease (IgG4-RD) is a fibroinflammatory disorder that may involve almost each organ or system. IgG4-related kidney disease (IgG4-RKD) refers to renal lesions associated with IgG4-RD. The most frequent morphological type of renal lesions is IgG4-related tubulointerstitial nephritis (IgG4-TIN) which is associated with increased IgG4positive plasma cell infiltration and interstitial fibrosis. Case Report: Herein, we present a rare case with coexisting IgG4-RKD and acute crescent glomerulonephritis with concomitant severe tubulointerstitial lesions instead of classic IgG4-TIN. Conclusion: IgG4-RKD and acute crescent glomerulonephritis can occur in the same patient. This case may give us a clearer viewpoint of the disease.




\section{Case Reports in Nephrology and Dialysis}

Lu et al:: Coexistence of Acute Crescent Glomerulonephritis and IgG4-Related Kidney Disease

\section{Introduction}

IgG4-related disease (IgG4-RD) is a potentially multiorgan disorder which is characterized by increased IgG4-positive plasma cell infiltration, tissue fibrosis, and elevated serum levels of IgG4 [1, 2]. IgG4-RD can affect nearly every organ or system, including the pancreas, aorta, lung, salivary and lacrimal glands, thyroid, and kidney. Prior studies have reported that renal lesions seem to occur in approximately $15 \%$ of patients. Now, IgG4-related kidney disease (IgG4-RKD) is used as a comprehensive term for renal lesions associated with IgG4-RD.

IgG4-RKD is a recently recognized autoimmune renal disease which often, but not always, presents with high levels of serum IgG4, proteinuria, and acute or chronic renal dysfunction. Many characteristic abnormalities can be observed by radiological examinations which may resemble malignant tumors. The most frequent histological finding is IgG4related tubulointerstitial nephritis (IgG4-TIN) which is associated with increased IgG4positive plasma cell infiltration and interstitial fibrosis [3, 4]. Although TIN is the predominant lesion type in IgG4-RKD, herein, we present a rare case with coexisting IgG4-RKD and acute crescent glomerulonephritis with concomitant severe tubulointerstitial lesions instead of classic IgG4-TIN.

\section{Case Report}

A 61-year-old Chinese woman was hospitalized due to elevated serum creatinine (Scr). Four months previously, without any predisposing factors, she had suffered from sudden dryness, burning, and paroxysmal pinprick-like pains in her right eye, accompanied by a headache in the right hemisphere. Her discomfort was obvious in the morning, while it was slightly relieved in the afternoon without any treatment. Computed tomography (CT) did not reveal any abnormality in the brain. Iritis and scleritis were considered by an ophthalmologist, but the symptoms were not alleviated after dexamethasone eyedrops. One day previously, laboratory tests had shown elevated Scr of $324 \mu \mathrm{mol} / \mathrm{l}$.

At physical examination, her body temperature was $36.6^{\circ} \mathrm{C}$, her pulse rate 100 beats per minute, and her blood pressure 125/68 mm Hg. She had no skin lesions or swollen lymph nodes. There were no rales on bilateral lungs and no murmurs in the heart. Her abdomen was soft, and there were no signs of swollen liver, spleen, or edema.

Lab test results were as follows: white blood cells $7.3 \times 10^{9} / \mathrm{l}$, red blood cells $2.89 \times$ $10^{12} / \mathrm{l}$, hemoglobin $76 \mathrm{~g} / \mathrm{l}$, and platelets $183 \times 10^{9} / \mathrm{l}$; urinary red blood cells $140 / \mu \mathrm{l}$, urinary occult blood (++), urinary white blood cells $6 / \mu \mathrm{l}$, and urinary protein $1.93 \mathrm{~g} / 24 \mathrm{~h}$. Blood biochemistry analysis provided the following results: total protein $66 \mathrm{~g} / \mathrm{l}$, albumin $31 \mathrm{~g} / \mathrm{l}$, alanine aminotransferase $32 \mathrm{U} / \mathrm{l}$, total bilirubin $9 \mu \mathrm{mol} / \mathrm{l}$, serum iron $7 \mu \mathrm{mol} / \mathrm{l}$, blood nitrogen urea $13.1 \mathrm{mmol} / \mathrm{l}$, Scr $324 \mu \mathrm{mol} / \mathrm{l}$, uric acid $385 \mu \mathrm{mol} / \mathrm{l}$, sodium $129 \mathrm{mmol} / \mathrm{l}$, potassium $3.8 \mathrm{mmol} / \mathrm{l}$, chloride $93 \mathrm{mmol} / \mathrm{l}$, and $\mathrm{CO}_{2} 18.3 \mathrm{mmol} / \mathrm{l}$. Clinical immunology tests revealed the following: anti-nuclear antibody (-), anti-neutrophil cytoplasmic antibodies (-), IgG 16.8 g/l, IgG4 $3.21 \mathrm{~g} / \mathrm{l}, \mathrm{C} 30.84 \mathrm{~g} / \mathrm{l}, \mathrm{C} 40.24 \mathrm{~g} / \mathrm{l}$, C-reactive protein $46 \mathrm{mg} / \mathrm{l}$, and erythrocyte sedimentation rate $58 \mathrm{~mm} / \mathrm{h}$. Serum immune electrophoresis was normal. Hepatitis virus screening was as follows: hepatitis B surface antigen (-), anti-hepatitis B surface antibody $(+)$, and anti-hepatitis $C$ antibody (-). Blood levels of lipid series, glucose, thyroid function, and tumor markers were all normal. 
Renal ultrasonography showed that the size of the right kidney was $98 \times 34 \mathrm{~mm}$, while the left one was $95 \times 40 \mathrm{~mm}$. The renal cortical echo was slightly enhanced, and no renal calculus was found. An enhanced CT scan indicated multiple low-density lesions under both of the renal capsules (fig. 1). Emission CT revealed chronic sialadenitis in the bilateral parotid glands.

Then, the patient underwent a renal biopsy. The immunofluorescence report found negative IgG, IgA, IgM, and C3. The pathological findings were as follows: there were 19 glomeruli in total, global sclerosis in 7 glomeruli, crescents forming in 10 glomeruli, and middle to severe mesangial cellular hyperplasia along with increased mesangial matrix in 2 glomeruli as well. There were diffuse tubular atrophy and extensively dense mononuclear cells among the tubulointerstitial tissues. Protein casts were also observed in some tubules. No obvious vascular lesions were found. Immunohistochemistry showed IgG4-positive plasma cells $>10 /$ high-power field (HPF), and the ratio of IgG4+ ${ }^{+}$cells to $\mathrm{IgG}^{+}$cells was $>40 \%$ (fig. 2). A pathological diagnosis of acute crescent glomerulonephritis with severe renal TIN damage was achieved.

Based on the physical examination, lab tests, and renal biopsy, the patient was diagnosed as IgG4-RKD combined with acute crescent glomerulonephritis after excluding vasculitis, Sjögren's syndrome, and plasmacytoma. The patient was treated with methylprednisolone $(1 \mathrm{mg} / \mathrm{kg}$ every day) and cyclophosphamide (1.0 g per month). In addition, tablets of calcium, iron, and proton pump inhibitors were used at the same time. Four weeks later, the Scr dropped from 324 to $213 \mu \mathrm{mol} / \mathrm{l}$, and symptoms were relieved. Furthermore, the Scr dropped to $130 \mu \mathrm{mol} / \mathrm{l}$ at the 16-week follow-up (fig. 3). At the same time, the serum IgG4 concentrations dropped to $1.21 \mathrm{~g} / \mathrm{l}$.

\section{Discussion}

IgG4-RKD is a recently defined term referring to renal lesions associated with IgG4-RD $[5,6]$. In this case of an aged female patient, presenting renal insufficiency, hematuria, albuminuria, low serum C3, and elevated serum IgG4, renal biopsy showed acute crescent glomerulonephritis combined with severe renal tubulointerstitial lesions. Moreover, the immunohistochemistry revealed IgG4-positive plasma cells $>10 / \mathrm{HPF}$ and the ratio of IgG4+ cells to $\mathrm{IgG}^{+}$cells was $>40 \%$. Irregular fibrosis located around the infiltrated lymphocytes could also be observed. In addition, the eye and the parotid gland were involved. Diagnostic criteria for IgG4-RKD have been proposed by Kawano et al. [7]. By using these criteria, the results can be separated into definite, probable, and possible. According to the diagnostic criteria for IgG4-RKD, the patient was diagnosed with definite IgG4-RKD [1, 7]. In IgG4-RKD, steroids are commonly effective in ameliorating kidney lesions and abnormalities of radiology or serology [8-10]. Although a high-dosed steroid treatment works rapidly in IgG4-RKD, a long-term maintenance of low-dosed therapy remains essential for the recovery of renal function [11]. In this case, after the treatment with steroid and cyclophosphamide pulse therapy, the patient's symptoms were relieved and the Scr became almost normal 16 weeks later.

This is the first report of IgG-RKD presenting with a pathological pattern of acute crescentic glomerulonephritis with severe renal tubulointerstitial injury. In earlier reports, IgG4RKD usually resulted in IgG4-TIN without specific signs of immunofluorescent staining. Furthermore, IgG4-RKD presented with increased plasma cell infiltration in the swelling interstitial tissues, and slight fibrosis could be observed in the early stage. At the late stage, multi- 
focal tubular atrophy in laminate structures could appear with a high number of IgG4positive plasma cells, and storiform fibrosis was also apparent [12-14]. Obliterative phlebitis is also a critical pathological feature of IgG4-RD, although it is rarely seen in IgG4-TIN [3]. However, apart from TIN, other pathology types induced by IgG4-RKD have also been discovered, such as membranous nephropathy, pyelonephritis, or glomerulonephritis as recently reported [13, 15-17]. Acute crescent glomerulonephritis combined with IgG4-RKD has never been reported yet.

IgG4-RKD often occurs in old male patients with hyperglobulinemia and high serum levels of IgG $[4,18]$. However, this case was an old female patient with anemia, maybe due to a long-term kidney injury. Another novelty of this case is that the histological type of the renal lesions was acute crescent glomerulonephritis with concomitant TIN. Also, TIN-uveitis syndrome and an atypical form of Cogan's syndrome should be differentiated from IgG4-RD in this case, since the patient presented with combined iritis and kidney damage [19,20].

As a recently clarified type of renal injury, IgG4-RKD is different from classic acute kidney injury or chronic kidney disease [21-23]. Usually, the renal pathological pattern of IgG4RKD is TIN. This case of acute crescent glomerulonephritis combined with IgG4-RKD may give us a clearer viewpoint of this disease. In the long run, the mechanisms of the crescent glomerulonephritis in the present case and the proportion of IgG4-RKD patients affected need further investigation and discussion.

\section{Acknowledgements}

This work was supported by the National Natural Science Foundation of China (grant No. 81570603) and Shanghai Pujiang Talent Projects (15PJ1406700).

\section{Statement of Ethics}

This case report was approved by the ethics committee of Shanghai Jiao Tong University Affiliated People's Hospital, and the patient provided informed consent.

\section{Disclosure Statement}

The authors have no conflicts of interest to declare.

\section{References}

1 Cortazar FB, Stone JH: IgG4-related disease and the kidney. Nat Rev Nephrol 2015;11:599-609.

-2 Stone JH, Chan JK, Deshpande V, Okazaki K, Umehara H, Zen Y: IgG4-related disease. Int J Rheumatol 2013;2013:532612.

3 Yamaguchi Y, Kanetsuna Y, Honda K, Yamanaka N, Kawano M, Nagata M; Japanese study group on IgG4related nephropathy: Characteristic tubulointerstitial nephritis in IgG4-related disease. Hum Pathol 2012;43:536-549.

-4 Saeki T, Nishi S, Imai N, Ito T, Yamazaki H, Kawano M, Yamamoto M, Takahashi H, Matsui S, Nakada S, Origuchi T, Hirabayashi A, Homma N, Tsubata Y, Takata T, Wada Y, Saito A, Fukase S, Ishioka K, Miyazaki K, Masaki Y, Umehara H, Sugai S, Narita I: Clinicopathological characteristics of patients with IgG4-related tubulointerstitial nephritis. Kidney Int 2010;78:1016-1023. 
-5 Umehara H, Okazaki K, Masaki Y, Kawano M, Yamamoto M, Saeki T, Matsui S, Sumida T, Mimori T, Tanaka Y, Tsubota K, Yoshino T, Kawa S, Suzuki R, Takegami T, Tomosugi N, Kurose N, Ishigaki Y, Azumi A, Kojima M, Nakamura S, Inoue D; Research Program for Intractable Disease by Ministry of Health, Labor and Welfare (MHLW) Japan G4 team: A novel clinical entity, IgG4-related disease (IgG4RD): general concept and details. Mod Rheumatol 2012;22:1-14.

-6 Saeki T, Kawano M: IgG4-related kidney disease. Kidney Int 2014;85:251-257.

7 Kawano M, Saeki T, Nakashima H, Nishi S, Yamaguchi Y, Hisano S, Yamanaka N, Inoue D, Yamamoto M, Takahashi H, Nomura H, Taguchi T, Umehara H, Makino H, Saito T: Proposal for diagnostic criteria for IgG4-related kidney disease. Clin Exp Nephrol 2011;15:615-626.

-8 Cornell LD: IgG4-related tubulointerstitial nephritis. Kidney Int 2010;78:951-953.

-9 Saeki T, Kawano M, Mizushima I, Yamamoto M, Wada Y, Ubara Y, Nakashima H, Ito T, Yamazaki H, Narita I, Saito T: Recovery of renal function after glucocorticoid therapy for IgG4-related kidney disease with renal dysfunction. Clin Exp Nephrol 2016;20:87-93.

10 Arai H, Hayashi H, Takahashi K, Koide S, Sato W, Hasegawa M, Yamaguchi Y, Aten J, Ito Y, Yuzawa Y: Tubulointerstitial fibrosis in patients with IgG4-related kidney disease: pathological findings on repeat renal biopsy. Rheumatol Int 2015;35:1093-1101.

11 Saeki T, Kawano M, Mizushima I, Yamamoto M, Wada Y, Nakashima H, Homma N, Tsubata Y, Takahashi H, Ito T, Yamazaki H, Saito T, Narita I: The clinical course of patients with IgG4-related kidney disease. Kidney Int 2013;84:826-833.

12 Watson SJ, Jenkins DA, Bellamy CO: Nephropathy in IgG4-related systemic disease. Am J Surg Pathol 2006;30:1472-1477.

13 Alexander MP, Larsen CP, Gibson IW, Nasr SH, Sethi S, Fidler ME, Raissian Y, Takahashi N, Chari S, Smyrk TC, Cornell LD: Membranous glomerulonephritis is a manifestation of IgG4-related disease. Kidney Int 2013;83:455-462.

14 Deshpande V, Zen Y, Chan JK, Yi EE, Sato Y, Yoshino T, Kloppel G, Heathcote JG, Khosroshahi A, Ferry JA, Aalberse RC, Bloch DB, Brugge WR, Bateman AC, Carruthers MN, Chari ST, Cheuk W, Cornell LD, Fernandez-Del Castillo C, Forcione DG, Hamilos DL, Kamisawa T, Kasashima S, Kawa S, Kawano M, Lauwers GY, Masaki Y, Nakanuma Y, Notohara K, Okazaki K, Ryu JK, Saeki T, Sahani DV, Smyrk TC, Stone JR, Takahira M, Webster GJ, Yamamoto M, Zamboni G, Umehara H, Stone JH: Consensus statement on the pathology of IgG4-related disease. Mod Pathol 2012;25:1181-1192.

15 Kurien AA, Raychaudhury A, Walker PD: Membranous nephropathy as a rare renal manifestation of IgG4-related disease. Indian J Nephrol 2015;25:164-167.

16 Kawano M, Saeki T: IgG4-related kidney disease - an update. Curr Opin Nephrol Hypertens 2015;24:193-201.

17 Katano K, Hayatsu Y, Matsuda T, Miyazaki R, Yamada K, Kawano M, Takahashi N, Kimura H, Yoshida H: Endocapillary proliferative glomerulonephritis with crescent formation and concurrent tubulointerstitial nephritis complicating retroperitoneal fibrosis with a high serum level of IgG4. Clin Nephrol 2007;68:308-314.

18 Takahashi N, Kawashima A, Fletcher JG, Chari ST: Renal involvement in patients with autoimmune pancreatitis: CT and MR imaging findings. Radiology 2007;242:791-801.

19 Brogan K, Eleftheriou D, Rajput K, Edelsten C, Sebire NJ, Brogan PA: Tubulointerstitial nephritis, uveitis, hearing loss and vestibular failure: TINU-atypical Cogan's overlap syndrome. Rheumatology 2012;51:950-952.

20 Espinoza GM, Prost A: Cogan's syndrome and other ocular vasculitides. Curr Rheumatol Rep $2015 ; 17: 24$

-21 Wang F, Zhang G, Lu Z, Geurts AM, Usa K, Jacob HJ, Cowley AW, Wang N, Liang M: SerpinC1 gene insufficiency exacerbates acute kidney injury in rats. Kidney Int 2015;88:796-803.

-22 Wang F, Yin J, Lu Z, Zhang G, Li J, Xing T, Zhuang S, Wang N: Limb ischemic preconditioning protects against contrast-induced nephropathy via renalase. EBioMedicine 2016, DOI: 10.1016/j.ebiom.2016.05.017.

23 Wang F, Zhang G, Xing T, Lu Z, Li J, Peng C, Liu G, Wang N: Renalase contributes to the renal protection of delayed ischaemic preconditioning via the regulation of hypoxia-inducible factor- $1 \alpha$. J Cell Mol Med 2015;19:1400-1409.

Z.L., J.Y. and H.B. contributed equally to this work. 


\section{Case Reports in Nephrology and Dialysis}

\begin{tabular}{l|l}
\hline Case Rep Nephrol Dial 2016;6:89-95 \\
\hline 10.1159/000448025 & $\begin{array}{l}\text { @ 2016 The Author(s). Published by S. Karger AG, Basel } \\
\text { www.karger.com/cnd }\end{array}$ \\
\hline
\end{tabular}

Lu et al.: Coexistence of Acute Crescent Glomerulonephritis and IgG4-Related Kidney Disease

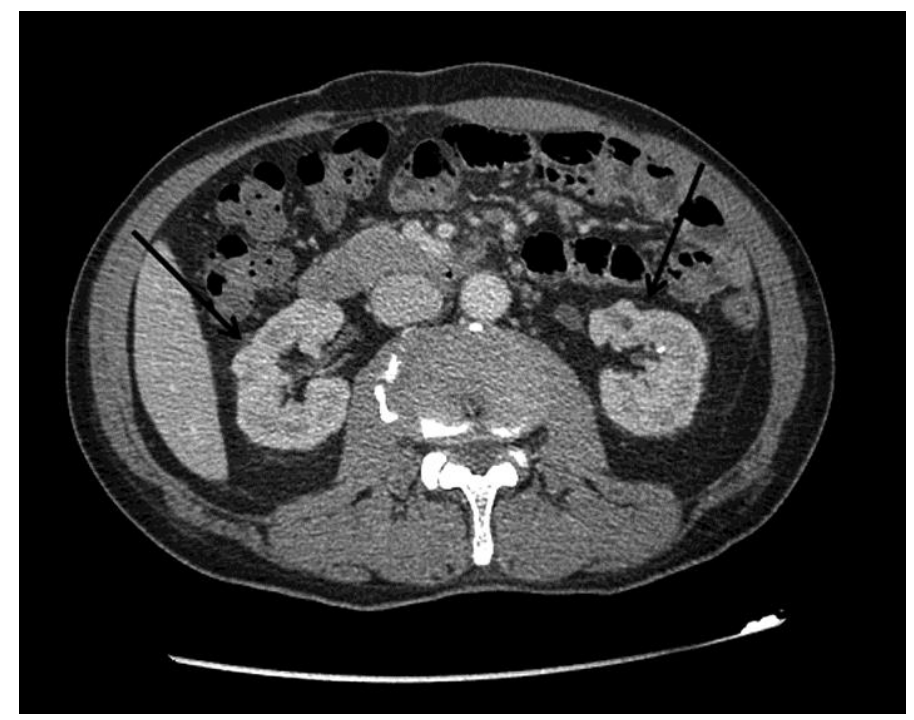

Fig. 1. Characteristic CT of the kidney. Multiple low-density lesions can be seen on enhanced CT.

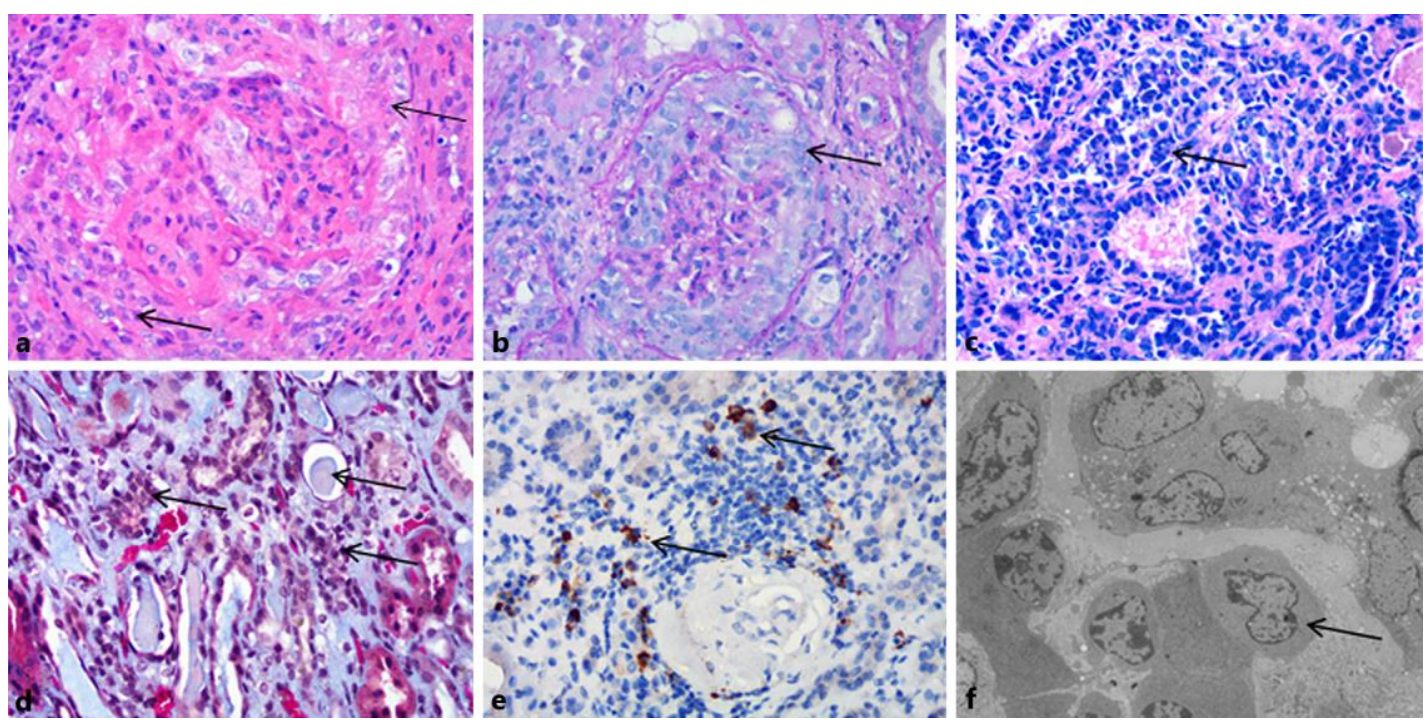

Fig. 2. Pathological findings of the renal biopsy. The major finding of the renal biopsy was acute crescent glomerulonephritis combined with severe TIN. a, b Extensive glomerular crescents have formed (a HE staining, $\times 400$; b periodic acid-Schiff staining, $\times 400$ ). $c$ Dense mononuclear cells have infiltrated the interstitium (HE staining, $\times 400$ ). $\mathbf{d}$ Tubular degeneration, atrophy, necrosis, inflammatory cell infiltration, and diffuse interstitial fibrosis were observed (trichrome staining, $\times 400$ ). e There were plenty of IgG4-positive plasma cells in the infiltrate (IgG4 staining, $\times 400$ ). $\mathrm{f}$ Infiltrated plasma cells or lymphocytes in the infiltrate (electron microscopy, $\times 5,000$ ). 


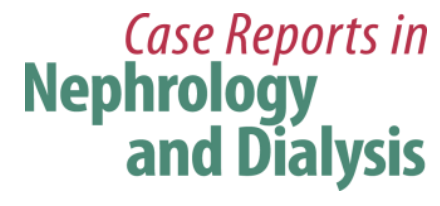

Case Rep Nephrol Dial 2016;6:89-95

$10.1159 / 000448025$

(C) 2016 The Author(s). Published by S. Karger AG, Basel www.karger.com/cnd

Lu et al.: Coexistence of Acute Crescent Glomerulonephritis and IgG4-Related Kidney Disease

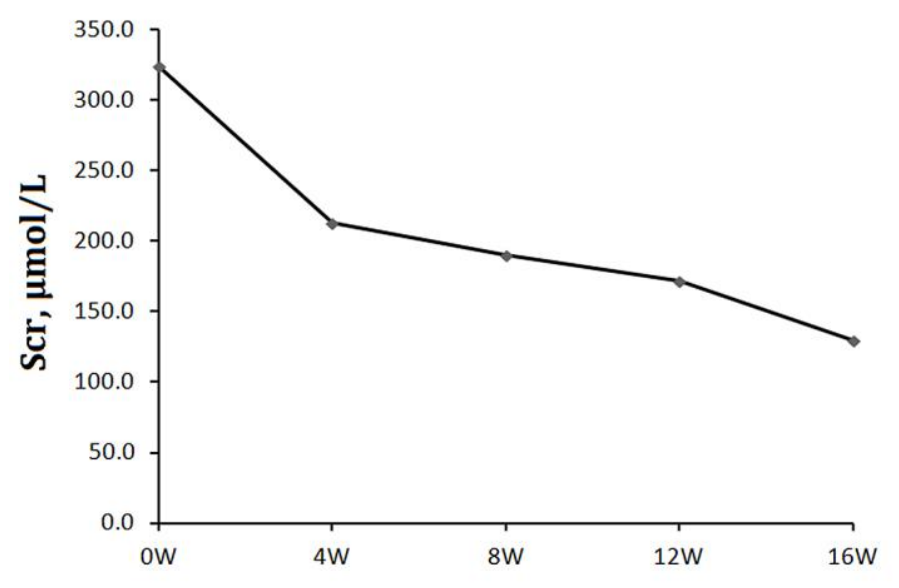

Fig. 3. Scr changes during follow-up. Scr levels decreased with the treatment of methylprednisolone and cyclophosphamide. $\mathrm{W}=$ Weeks. 